\title{
"Whenever society is in travail liberty is born": The mass strike of 1919 in colonial Trinidad
}

\section{Christian Høgsbjerg}

"Our inherent rights receive emphasis and new assertion at moments of political stress and strain, for whenever society is in travail liberty is born. Evolution is the outcome of revolution, and advancement in any sphere of human activity is expedited by epochal upheavals." So argued David Headley, a leading figure in the social democratic nationalist Trinidad Workingmen's Association (TWA) in the aftermath of the mass strike of 1919 in the Crown Colony of Trinidad. ${ }^{1}$ Though a small island with a population of some 312,790 in 1911, the subsequent growth of the TWA into a mass organisation during the 1920s vindicated such radical words, which themselves give a sense of the new feeling of empowerment and confidence felt by workers. ${ }^{2}$ This essay will explore how 1919 saw a rolling mass strike that would shake this outpost of the British Empire to its foundations. Though often located as an important part of Caribbean labour history - a precursor in many ways to the powerful wave of regional rebellions in the 1930s - this essay will examine the strike through a transnational prism. It will explore how the strike not only had indigenous roots relating to the workers' resentment that had steadily built up during the Great War but also international ones - such as the experience by black Trinidadians of popular racism in imperial Britain and institutional racism by black colonial troops in the British West Indies Regiment (BWIR). It will also situate the strike within the wider international industrial turmoil of that year - not least the rising militancy of organized labour in imperial Britain itself. In the process it aims to explore the potentialities for - and limitations of international solidarity in 1919, when the British Empire was perhaps at the height of its power.

\section{Local and Global Roots of a Mass Strike}

With the outbreak of the Great War in 1914, there was a great show of imperial loyalty at the outset from colonial subjects, with some 16,000 black West Indians answering the call to defend the British Empire. Marcus Garvey, the Jamaican Pan-Africanist and founder of the Universal Negro Improvement Association (UNIA), had given his blessings, arguing that it "was the duty of every true son of the Empire to rally to the cause of the Motherland [Britain]". ${ }^{3}$ Yet workers' resentment grew as the bloody conflict dragged on. In Trinidad, devoid of elected representatives above the municipal level, and governed by officials appointed by the Crown headed by a governor, anger at price rises and mercantile profiteering amid low wages, underemployment and unemployment slowly escalated. In spring 1917, oilfield, dock and asphalt workers in the south in Point Fortin, Brighton, La Brea and Fyzabad took strike action, particularly against the United British Oilfields company and

\footnotetext{
${ }^{1}$ Headley in the Monographic Labour Review, 1 (1921), quoted in Kelvin Singh, Race and Class Struggles in a Colonial State: Trinidad 1917-1945, Kingston, University of the West Indies Press, 1994, 23. My thanks to David Featherstone for comments on this article in draft.

2 Brinsley Samaroo, “The Trinidad Workingmen’s Association and the Origins of Popular Protest in a Crown Colony”, Social and Economic Studies, 21, 2 (1972), 205.

${ }^{3}$ Adam Ewing, “Caribbean labour politics in the age of Garvey, 1918-1938”, Race \& Class, 55, 1 (2013), 27.
} 
the American owned Trinidad Lake Asphalt Company. Striking oil workers in Brighton set Trinidad Lake Asphalt Company buildings ablaze, leading to the arrests of fifteen strike leaders (with two sentenced to two years hard labour). These strikes, as Kelvin Singh notes, "fizzled out as the workers yielded to threats of eviction from the company's barracks and of outright dismissal". 4 The colonial government also now passed repressive legislation such as the Habitual Idlers Ordinance (1918), which stated every male worker should be forced to work in new government-run "agricultural settlements" if necessary, where they might learn the "habits of industry". 5

One beneficiary of the workers' strike action of 1917 however was the TWA, which now established a branch at La Brea. ${ }^{6}$ Founded in 1894 and inspired by organisations like the London Workingmen's Association of the 1830s and the Leeds Workingmen's Parliamentary Reform Association of 1861, the TWA's early efforts to champion workers' rights in a colonial dictatorship was a true "labour of Sisyphus". Letters and petitions were replied to in a "derisive and irrelevant" manner by officials when not just "quietly assigned to the wastepaper basket". The TWA was re-organised and inaugurated in 1906 with some 233 members and immediately sought and won affiliation to the British Labour Party. ${ }^{7}$ At this time, as Singh notes, the Labour Party "would use colonial issues as propaganda weapons against its Liberal and Tory domestic opponents in and out of parliament". ${ }^{8}$ From 1906 until 1910, Labour MP for Sunderland Thomas Summerbell championed TWA causes in parliament. From 1910, Joseph Pointer, the first Labour MP for Sheffield, assiduously picked up Summerbell's baton, earning the nickname from parliamentary colleagues "the member of Trinidad". Pointer toured Trinidad in 1912 with the TWA, speaking at meetings including one 3,000 strong rally in the capital Port-of-Spain where he praised the TWA for its inclusion of working class women. ${ }^{9}$

During 1917, international developments, including the hopes fired in the hearts of black colonial subjects globally by the Russian Revolution helped encourage a new emerging radical mood in the TWA. As Brinsley Samaroo notes, "the diversity of Trinidad's economy meant that ships of many European nations visited Port of Spain either for trade or for refueling ... a wide range of literature was brought into the colony ... potential and active agitators were exposed to a wide range of European ideas ... the post-war period was

\footnotetext{
4 Singh, Race and Class Struggles, 22. See also Ron Ramdin, From Chattel-slave to Wage-earner: A History of Trade Unionism in Trinidad and Tobago, London, Martin Brian \& O'Keeffe, 1982, 51; and Jerome Teelucksingh, Labour and the decolonisation struggle in Trinidad and Tobago, Basingstoke, Palgrave Macmillan, 2015, 32.

${ }^{5}$ Ray Kiely, “The Politics of Labour and Development in Trinidad and Tobago”, PhD, University of Warwick, 1991, 118. Singh, Race and Class Struggles, 13.

${ }^{6}$ Singh, Race and Class Struggles, 22.

${ }^{7}$ Samaroo, “The Trinidad Workingmen’s Association”, 206-208; Teelucksingh, Labour and the decolonisation struggle, 20.

${ }^{8}$ Singh, Race and Class Struggles, 10.

9 Teelucksingh, Labour and the decolonisation struggle, 20-22, 48. See also Samaroo, “The Trinidad Workingmen’s Association”, 208.
} 
increasingly 'Socialist' in the way that West Indians understood the term”. ${ }^{10}$ In early 1919, TWA radicals read reports of the rising levels of class struggle in Britain, not least the mass strike and resulting tumult in Glasgow's Clydeside for the 40 hour week which had seen over 40,000 engineers and shipbuilders on strike alongside 36,000 miners and electricity supply workers. The Secretary State for Scotland, Robert Munro argued in January 1919 that "it was a misnomer to call the situation in Glasgow a strike - it was a Bolshevist uprising”, and 12,000 English troops, 100 lorries and six tanks were deployed to maintain order. ${ }^{11}$

In Trinidad, workers' were also on the march in early 1919 and council workers, civil servants, railway workers and dockworkers among others all agitated for higher pay. ${ }^{12}$ In March 1919, dockworkers and railway workers took strike action. ${ }^{13}$ The TWA now unanimously voted to make representations on behalf of any group of workers to the government or their employers, and also to accept affiliation from any group of workers. In May 1919 the TWA helped win a 33.3\% pay rise for oilfield workers at La Brea in dispute with the Trinidad Lake Asphalt Company, a tremendous victory. ${ }^{14}$

Summer 1919 brought less welcome news from Britain, of horrendous bloody racist riots by demobilised British soldiers and sailors directed against mainly black colonial seafarers that were in the process of sweeping the port areas of some of Britain's largest cities including Liverpool, Glasgow, London, Cardiff, Manchester as well as Hull, Barry and Newport which left five dead and countless numbers seriously wounded. ${ }^{15}$ As Adam Ewing notes, the local press featured "reports of gangs of white soldiers and sailors 'savagely attacking, beating and stabbing every negro they could find' in the streets of Liverpool, including a Trinidadian, Charles Wootten”, who was effectively lynched. ${ }^{16}$ On 17 July 1919, black people who had experienced the race riots in Cardiff returned to Trinidad, and one progressive local paper, the Argos, had reported a widely circulated story of how a white mob in Cardiff had apparently attacked a black man's funeral, cut off the corpses head, and used it as a football. ${ }^{17}$

\footnotetext{
${ }^{10}$ Samaroo, “The Trinidad Workingmen’s Association”, 218-19.

${ }^{11}$ Satnam Virdee, Racism, Class and the Racialised Outsider, Basingstoke, Palgrave Macmillan, 2014, 77; Chanie Rosenberg, 1919: Britain on the brink of revolution, London, Bookmarks, 1987, 30-31. See also Paul Griffin, "Labour struggles and the formation of demands: The spatial politics of Red Clydeside”, Geoforum, 62 (2015), 121-130.

12 Teelucksingh, Labour and the decolonisation struggle, 32-33.

${ }^{13}$ Singh, Race and Class Struggles, 23.

14 Teelucksingh, Labour and the decolonisation struggle, 33. See also Kiely, “The Politics of Labour and Development”, 118, and Ramdin, From Chattel-slave to Wage-earner, 56.

${ }^{15}$ Virdee, Racism, Class and the Racialised Outsider, 79. See also Jacqueline Jenkinson, Black 1919: Riots, Racism and Resistance in Imperial Britain, Liverpool, Liverpool University Press, 2008.

${ }^{16}$ Ewing, “Caribbean labour politics”, 28.

17 Tony Martin, “Revolutionary Upheaval in Trinidad, 1919: Views from British and American Sources”, The Journal of Negro History, 58, 3 (1973), 318.
} 
Also now returning to the colony were demobilised BWIR troops who had had their own direct experiences of racism. As Adam Ewing notes, "Disembarking in Alexandria, Egypt, Samuel A. Haynes and his regiment arrived at their base camp YMCA 'under the strains of Rule Britannia', only to be 'immediately confronted by a number of British soldiers and asked, "Who gave you niggers authority to sing that! Clear out of this building - only British soldiers admitted here”'."18 One South African camp commandant with the British Army defended the fact that after the war, BWIR troops were used as latrine cleaners at Taranto in southern Italy on the grounds they "were only niggers and were better fed and clothed than any nigger had a right to expect". ${ }^{19}$ In December 1918, the black troops of ninth battalion of the BWIR in Taranto fought back. Their mutiny was brutally repressed, with one execution by firing squad, plus the arrests of fifty to sixty men (many of whom were imprisoned for years afterwards) and the disarmament of eight battalions. The Taranto revolt represented for W.F. Elkins "the modern advent of mass resistance by West Indians to British rule”. Some fifty or so black BWIR sergeants formed the Caribbean League, which before it was discovered and broken up had agreed on organizing a general strike for higher wages equal to white soldiers after repatriation. One Caribbean League leader argued that the black man "should have freedom and govern himself in the West Indies and ... force must be used, and if necessary bloodshed to obtain that object". ${ }^{20}$

The anger of BWIR veterans as they returned home in July 1919 to unemployment, underemployment, food price rises, rises in the cost of living, poverty and overcrowded housing was the spark that threw many British colonies into turmoil. Strikes and riots rocked Jamaica and Belize, British Honduras. ${ }^{21}$ In Trinidad, on 19-21 July returning soldiers were given pride of place at a parade to mark the Peace Celebrations, but only 132 soldiers fell in. As the local Inspector General of Constabulary, Colonel May, noted, many of the veterans were disappointed they were not going to be armed for the occasion as "some who had possessed themselves of ammunition whilst on active service intended to load with ball cartridges during the feu de joi and shoot down all the officers". ${ }^{22}$ Unable to take their resentment out on white officers, the black soldiers waited until it was dark and then attacked visiting white sailors of HMS Dartmouth, in Port of Spain for the Peace Celebrations. ${ }^{23}$ As Ron Ramdin notes, the elite paper Trinidad Guardian reported "the soldiers had 'run amok' because of anger over the arrival of the transport ship Oriana, which brought their comrades who had been convicted of mutiny at Taranto. The news of attacks on blacks in Britain increased hostility among the soldiers towards colonial rule."24

\footnotetext{
${ }^{18}$ Ewing, “Caribbean labour politics”, 27-28.

${ }^{19}$ Samaroo, “The Trinidad Workingmen’s Association”, 212.

${ }^{20}$ W.F. Elkins, "A Source of Black Nationalism in the Caribbean: The Revolt of the British West Indians Regiment at Taranto, Italy”, Science and Society, 34, 1970, 99, 102-103.

${ }^{21}$ Elkins, “A Source of Black Nationalism in the Caribbean”, 103; Ewing, “Caribbean labour politics”, 29.

${ }^{22}$ Martin, “Revolutionary Upheaval in Trinidad”, 315.

${ }^{23}$ Singh, Race and Class Struggles, 17.

${ }^{24}$ Ramdin, From Chattel-slave to Wage-earner, 54.
} 
Figures among the local white colonial elite like George F. Huggins, president of the Chamber of Commerce, now called for the arming of the colony's white men and the stationing of a permanent garrison of troops as "wild and persistent rumors about the blacks rising in a body against the whites" circulated. ${ }^{25}$ On 30 July 1919 a private letter penned by influential white citizens was sent to the Colonial Secretary which warned "a substantial minority of the black population openly proclaims it has no further use for the white man, and means to eliminate him". They also (perceptively) feared the emergence of the "creole coolie” with the end of indentureship across the British Empire in 1917, a new East Indian in the West Indies who would now choose to ally with the black majority rather than act as a "substantial safeguard" for the white minority. ${ }^{26}$

By August 1919, BWIR veterans in Trinidad had formed the "Returned Soldiers and Sailors Council” - soon to be led by Captain Arthur Andrew Cipriani - a white Trinidadian BWIR officer who had defended the Taranto mutineers - to agitate for material support befitting their contribution during the war. ${ }^{27}$ In September 1919, there was a mutiny on the SS Orca, carrying black seafarers and military prisoners of the BWIR - one black man was killed and another wounded. ${ }^{28}$ The BWIR veterans' agitation led to a growth in membership of the TWA, as many former soldiers now joined.

On 7 October 1919, the British government wrote a secret document, "Unrest among the Negroes", which noted recent "slight disturbances in British Honduras and Jamaica” and remarked that "it is certain that the various negro associations in the United States will not leave the British Colonies alone". The report also noted that "an educated negro named F.E.M. Hercules arrived in Jamaica on the $5^{\text {th }}$ July. Up till the $14^{\text {th }}$ August he has done nothing on which any action against him could be taken, but it was significant that there was a strike in the workshop of the Jamaica Government Railway after he had addressed the men. There has also been a strike among the dock labourers." 29 Born in 1888, Felix Eugene Michael Hercules had attended Trinidad's elite Queen's Royal College, where he played a leading role in the Young Men's Coloured Association before becoming a civil servant and then a teacher. Around 1914, Hercules had moved with his young family to England to do an intermediate B.A. degree at London University. He now emerged as a leader of London's black community and an articulate Pan-Africanist, connected to the London-based Society of the Peoples of African Origin (SPAO) and editor of its publication, The African Telegraph. In December 1918, in an article on "The African and Nationalism”, Hercules explained that

\footnotetext{
${ }^{25}$ Singh, Race and Class Struggles, 18; Ewing, “Caribbean labour politics”, 30.

${ }^{26}$ Martin, "Revolutionary Upheaval in Trinidad", 319. See also W.F. Elkins, "Black Power in the British West Indies: The Trinidad Longshoreman’s Strike of 1919”, Science and Society, 33, 1969, 73.

${ }^{27}$ Singh, Race and Class Struggles, 16-20. Cipriani would in the 1920s play a leading role in Trinidadian nationalism. See C.L.R. James, The Life of Captain Cipriani: An Account of British Government in the West Indies with the pamphlet The Case for West Indian Self-Government, Durham, NC, Duke University Press, 2014.

${ }^{28}$ David Featherstone, "Politicizing In/Security, Transnational Resistance, and the 1919 Riots in Cardiff and Liverpool”, Small Axe, 57 (November 2018), 64-65.

${ }^{29}$ W.F. Elkins, “'Unrest among the Negroes’: A British document of 1919”, Science and Society, 32 (1968), 7274.
} 
“Time was when I deemed myself an Internationalist ... If I had never come to England I might even now be an Internationalist”.

But England with its barriers and prejudices, its caste system as rigid as any practiced by the Hindoo, Western civilisation with its sham and hypocrisy, with its conventionalities and its deification of Money and Force where one hoped to find Christ, these things it is that have driven me to the refuge of my own people... and yet I have remained sufficiently catholic to believe that the day will surely come when men of every nationality and of every race will look back of colour, back of superficial difference, and see clearly the brotherhood in man... ${ }^{30}$

In early September 1919, after his visit to Jamaica, Hercules returned to Trinidad for a short lecture tour, and was welcomed by the Argos, who offered a "hearty welcome" to this "son of the soil" who from his schooldays "was imbued with love for his race and the desire to do something to better its condition". ${ }^{31}$ On 11 September 1919 Hercules gave a lecture about the SPAO, declaring his address would be "on purely racial lines" but was not about stirring up racial animosity. He recounted the indignities suffered by black people in South Africa, and the outrages seen in the race riots in London, Liverpool and Cardiff and argued the "Coloured Race" was faced with such a crisis in its history that without the unity and cooperation of blacks they would revert to the condition of slavery, 80-100 years ago. For Hercules, as the Argos reported, the solution was that "peoples of African origin, regardless of pigment, should acquire racial consciousness", that "they should get to know each other and act in sympathy and unison", and "they should strive to acquire a measure of economic independence, by which alone they would be able to fight their present disabilities". ${ }^{32}$

\section{The Mass Strike}

By October 1919, the dockworkers in Port of Spain - the sector with the strategic power to strategically hit the monopoly merchants who controlled trade and the supply of basic food stuffs into the colony - were indeed showing signs of an increasing desire to "act in sympathy and unison". Already in 1919, there had been a longshoremen's strike on the Panama Canal, a mass harbour strike in New York and a successful dockworkers' strike in British Guiana. Trinidad's dockworkers experienced rising living costs, subsistence wages and precarious work patterns, with underemployment a common feature of life, but faced a repressive shipping company management without any institutionalised bargaining system - and also an element of conservatism in the TWA leadership with respect to supporting dockworkers' strike action. ${ }^{33}$ Nonetheless, the intransigence of the shipping company employers and the colonial government in neither recognising nor acknowledging those workers who tried to organise through the TWA, now provoked a mass dockworkers strike on 15 November 1919, one that would rock the Port of Spain waterfront for three weeks. This was, as Singh rightly

\footnotetext{
${ }^{30}$ F.E.M. Hercules, “The African and Nationalism”, The African Telegraph, 1/8 (December 1918), 84.

${ }^{31}$ W.F. Elkins, “Hercules and the Society of Peoples of African Origin”, Caribbean Studies, 11, 4, $1972,56$.

32 Singh, Race and Class Struggles, 21-22. After Trinidad, Hercules left for British Guiana, and the fears colonial authorities had in him is testified by fact that in middle of December 1919, Hercules was forbidden to re-enter Trinidad.
}

${ }^{33}$ Singh, Race and Class Struggles, 23-24; Teelucksingh, Labour and the decolonisation struggle, 34. 
notes, "the decisive event of the year" in the colony, and within a week "the dockworkers' strike had a catalytic effect on other sections of the working population in Port of Spain”.

On 21 November city council workers struck for higher pay. On 24 November female coal-carriers employed with the Archer Coaling Company also struck and signified their intention of joining the TWA. On the same day labourers on the estate of the Trinidad Land and Finance Company struck, as did vendors who supplied [char]coal to the city, among whom were Indian wholesalers. In the meantime lower ranking civil servants and shop assistants, mostly black or of mixed ancestry, seized the opportunity to press for a war bonus and higher wages respectively. ${ }^{34}$

On 1 December 1919, just as the shipping company employers felt the dockworkers' strike itself was collapsing, strikers stepped up their action and chased off the strike-breakers that had to that point been deployed and forced the closure of two of the warehouses. The strikers then took to the streets, marching into Port of Spain when accompanied by thousands of supporters they roamed around the business district of the capital city, shutting it down. ${ }^{35}$ As W.F. Elkins notes, “'Zaffaire Sho!' (things are hot!), exclaimed an old woman at the onset of violence, 'affaire sho asso Che la' (things are hot on the wharf)”. ${ }^{36}$ C.L.R. James - a recent graduate from Queen's Royal College working as a teacher at the time - later recalled how striking dockers "patrolled the town, made business close down, and were at one time in charge of the city". ${ }^{37}$ "It was the shutters and doors of Capital which, as it were, saluted as the army of strikers passed on its way through the streets of the city", noted the local Catholic News. ${ }^{38}$

Colonel May, the Inspector-General of Constabulary and the Commandant of the Local Forces, refused to order the (mostly black and underpaid) police to use their batons or open fire on the crowd, sensing the reluctance of the rank and file to follow such an order. May was also conscious of the risk of deploying the white-only Merchants Contingent of former soldiers against a predominantly black populace. Instead, he requested a meeting with the strikers, and managed to set up an arbitration committee including representatives of both strikers and the shipping companies to strike a deal, bringing the dockworkers' strike to an end on 3 December 1919, just as the British warship HMS Calcutta sailed into Port of Spain. The dockworkers accepted an offer of a 25 percent pay rise from the shipping companies, and the re-employment of the strikers. ${ }^{39}$ As Ron Ramdin notes, Aaron Braithwaite, acting secretary of the TWA, "broke the welcome news to 2,000 workers who had assembled in

\footnotetext{
34 Singh, Race and Class Struggles, 22, 25-27.

${ }^{35}$ Singh, Race and Class Struggles, 26-27; O. Nigel Bolland, On the March: Labour Rebellions in the British Caribbean, 1934-39, Kingston, Ian Randle, 1995, 31.

${ }^{36}$ Elkins, “Black Power in the British West Indies”, 73-74.

37 C.L.R. James, A History of Negro Revolt, London, FACT, 1938, 75.

${ }^{38}$ Elkins, “Black Power in the British West Indies”, 71.

${ }^{39}$ Singh, Race and Class Struggles, 27-28. See also Elkins, “Black Power in the British West Indies”, 74;

Ramdin, From Chattel-slave to Wage-earner, 61.
} 
Woodford Square. In addition ... the TWA was formally recognised as the organising agent for the waterfront workers." 40

This outcome infuriated the white colonial elite. Edgar Tripp, secretary of both the Agricultural Society and the Chamber of Commerce, denounced "one of the most humiliating surrenders to brute force that had ever been known in a British colony". Tripp attacked "the disgraceful incompetence of the authorities" and warned "the hooligans of Trinidad, whose mission appears to be to take Trinidad back to the condition of Haiti, should know that Trinidad was conquered by the British and would remain the property of the British". ${ }^{41}$ Yet for the workers and their supporters, this victory, won through the most militant forms of action, was inspirational. It now triggered what O. Nigel Bolland notes was "virtually a general strike" that rolled across Trinidad and even reached Tobago into early 1920, encompassing other groups of workers from Indian estate workers to oilfield workers in the South. ${ }^{42}$ As Singh notes,

Emboldened by the success of the dockworkers and the radical leadership of the TWA, other workers in the city, in rapid succession, went on strike: porters, grasscutters who supplied the city with fodder, scavangers and carpenters. In the first three occupations Indians predominated, so that at this stage of the growing unrest the strike movement was beginning to cross ethnic boundaries within the working class. All these 'malcontents' were reported to have stormed the office of the TWA to have their cause represented by that body - firm testimony to its growing authority among urban workers. ${ }^{43}$

Class consciousness began to trump that of race, as East Indians and blacks began to unite for the first time in solidarity. The movement spread to Tobago, where on 6 December 1919 there was a strike by estate workers as well as government employed carpenters. When rioters in Tobago attacked a government wireless station with stones and bottles they were repressed by troops from HMS Calcutta who fired on a crowd and killed two people. ${ }^{44}$ Jerome Teelucksingh describes how “at Trinidad's Central Oilfields, workmen and fitters went on strike demanding a $25 \%$ salary increase; likewise, striking scavengers employed by the city council demanded a 50\% salary increase. Strike action spread to the plantation sector and at the Woodford Lodge Estate, Lal Beharrysingh, one of the workers, was killed." 45 This East Indian worker was trying to persuade a crowd of his fellow estate labourers to strike the white overseer of the estate was arrested and charged with murder. ${ }^{46}$ Though the official local Indian organisations, the East Indian National Congress and the East Indian National

\footnotetext{
${ }^{40}$ Ramdin, From Chattel-slave to Wage-earner, 59.

${ }^{41}$ Martin, “Revolutionary Upheaval in Trinidad”, 323; Singh, Race and Class Struggles, 29.

42 Bolland, On the March, 30-32.

${ }^{43}$ Singh, Race and Class Struggles, 30.

44 Teelucksingh, Labour and the decolonisation struggle, 35; Singh, Race and Class Struggles, 31; Kiely, "The Politics of Labour and Development”, 119.

45 Teelucksingh, Labour and the decolonisation struggle, 35.

${ }^{46}$ Ramdin, From Chattel-slave to Wage-earner, 60.
} 
Association, advised their members to abstain from "violent and disgraceful conduct" and trust in the "British sense of honour and fairplay", coming so soon after the Amritsar massacre it is not surprising many East Indian workers nonetheless joined in the struggle against starvation wages and colonial domination. ${ }^{47}$

On 9 December 1919, Henry A. Baker, the local American Consul reported that "there are serious indications from many directions that Trinidad, and perhaps the British West Indies generally, are on a social volcano ... which is liable to burst into eruption at any time". ${ }^{48}$ The British now ordered the deployment of 350 troops from the second battalion of the Royal Sussex Regiment, at the time based in Jamaica, to restore order. ${ }^{49}$ After they arrived on New Years' Eve, the Governor Sir John Robert Chancellor reported their presence had a "sedative effect on the blacks". ${ }^{50}$ Yet workers' resistance continued, and on 5 January 1920 a strike erupted at the United British West Indies Petroleum Syndicate at Point Fortin, followed on 8 January by workers at the United British Oil Company. ${ }^{51}$ Oil workers now demanded equal pay between "native oil drillers" and "European oil drillers". ${ }^{52}$ On 9 January 1920, cocoa porters struck and on 12 January print workers at the Trinidad Guardian also struck for higher pay, and then on 14 January various groups of tailors joined the fight. ${ }^{53}$

\section{Rise of the TWA: Socialism, Garveyism and Black Power}

The chief political beneficiary of this workers' revolt was the TWA, which in mid-November 1919 had already grown to some 1,152 members nationally and now grew further. ${ }^{54}$ As Teelucksingh notes, "the Trinidad Guardian suggested the labour disturbances were part of a revolutionary plot to overthrow the government". ${ }^{55}$ Yet though many TWA members wore red shirts in solidarity with the Russian Revolution and while editorials in the local press sternly warned of the danger of "Bolshevism extending to Trinidad", it was the radical PanAfricanist ideas of Marcus Garvey rather than revolutionary socialism that captured the imagination of most leading strikers. ${ }^{56}$ As Colonel May put it in his report, the leaders of the strike were "imbued with the idea that there must be a black world controlled and governed

\footnotetext{
${ }^{47}$ Singh, Race and Class Struggles, 31.

48 Ewing, “Caribbean labour politics”, 28.

49 Teelucksingh, Labour and the decolonisation struggle, 35; Singh, Race and Class Struggles, 31.

50 Samaroo, “The Trinidad Workingmen’s Association”, 215.

51 Teelucksingh, Labour and the decolonisation struggle, 36-37.

52 Samaroo, “The Trinidad Workingmen’s Association”, 218.

${ }^{53}$ Singh, Race and Class Struggles, 32.

54 Singh, Race and Class Struggles, 24.

55 Teelucksingh, Labour and the decolonisation struggle, 35.

56 Cedric J. Robinson, Black Marxism: The Making of the Black Radical Tradition, London, Zed, 1991, 363; Susan Campbell, “Carnival, Calypso and Class Struggle in Nineteenth Century Trinidad,” History Workshop Journal, 26 (1988), 20.
} 
by the black people of their own race”, meaning that, as Elkins put it, "the strike demonstrations, therefore, represent a foretaste of Black Power in the British West Indies". ${ }^{57}$

Garvey's paper, the Negro World, was published in New York and circulated in Trinidad via seafarers on North American steamships, spreading a doctrine of racial justice and black unionization and labour radicalism in pursuit of racial goals and African liberation. On 7 June 1919, the Negro World declared that "signs are abundant that the future of the Negro race the world over is inextricably intertwined with the future of radicalism and labor". In August 1919, a mass Garveyite meeting had taken place at Chaguanas, western Trinidad. ${ }^{58}$ Baker, the American Consul, argued the Negro World was primarily "responsible for the rapid growth of class and race feeling, and of anarchistic and Bolshevist ideas among the ignorant population” of Trinidad. ${ }^{59}$ C.L.R. James knew a few of the strike-leaders through playing cricket, and later recalled he felt "positive that they were Garveyites". ${ }^{60}$ Adam Ewing notes that “during the strike TWA meetings often became de facto UNIA rallies”.

According to witnesses, at one meeting James Brathwaite, the TWA's secretary and local UNIA officer, repeated nearly verbatim the argument that Garvey had been making in the pages of the Negro World. 'You are a powerful race and our power was proved in the gigantic struggle for British liberty,' Brathwaite thundered. 'You don't think it is a shame for the intelligent negro to remain sleeping and waiting for amelioration? No, we must fight. If we can die for the white man against his German brother we can die better for ourselves. ${ }^{, 61}$

In this period, Garvey's often militant rhetoric clearly fitted with the new mood of resistance, and he declared in 1920 that the colours of the UNIA flag "showed their sympathy with the 'Reds' of the world, and the Green their sympathy for the Irish in their fight for freedom". However, Garvey himself was no revolutionary, once reminding an audience that though the Bolsheviks deserved the praise of black people, "we are not very much concerned as partakers in these revolutions". ${ }^{62}$ Indeed, though Garvey's ideas were mobilised by TWA leaders during 1919 in an anti-capitalist and anti-imperialist direction (which may in fact have surprised Garvey himself), far from acting as revolutionaries, TWA leaders often played a role during the height of the unrest akin to that played by a classic trade union leader or reformist politician, trying to urge strikers back to work. Amid the strike, the Governor had conceded that recognition ought to be given to the TWA, since it "had now great influence among the working classes, and by meeting representatives of the Association on the Wages

\footnotetext{
${ }^{57}$ Elkins, “Black Power in the British West Indies”, 75.

${ }^{58}$ Ewing, “Caribbean labour politics”, 29; Elkins, “'Unrest among the Negroes’, 67; Singh, Race and Class Struggles, 21.

${ }^{59}$ Martin, “Revolutionary Upheaval in Trinidad”, 326.

${ }^{60}$ Kent Worcester, C.L.R. James: A Political Biography, Albany, State University of New York Press, $1996,14$.

${ }^{61}$ Ewing, “Caribbean labour politics”, 30.

${ }^{62}$ Ahmed Shawki, Black Liberation and Socialism, Chicago, Haymarket, 2006, 103, 105.
} 
Committee, the employers might be able to ensure industrial peace in the colony for a number of years". 63

In the aftermath of the strikes, the colonial government clamped down hard, and 82 strikers were either fined or arrested, while some strike leaders and leading TWA members were fined, imprisoned and three deported. ${ }^{64} \mathrm{~A}$ barrage of repressive legislation followed including the Strikes and Lockouts Ordinance, to try and delay strikes and the Firearms Amendment Ordinance, restricting access to firearms (even for gunsmiths and gun-dealers), and there was a refusal to consider the legalisation of trade union activity (as had happened in Guyana and Jamaica). The 1920 Sedition Ordinance - allowing a maximum fine of $£ 1,000$ for anyone convicted of "seditious intention" with or without imprisonment of up to two years - meant the Governor now had the power to suspend any newspaper deemed to have contained seditious matter, and he promptly banned the Negro World and the Crusader among others. Courts could authorise the police to break, enter and search any building or place specified in the warrant, day or night. ${ }^{65}$ One calypsonian, Lord Protector (Patrick Jones, known as "Chinee Patrick" because of his Chinese heritage), was threatened with arrest and imprisonment for his song "Class Legislation” (1920), which noted that "Class legislation is the order of the land, We are ruled with an iron hand". ${ }^{66}$ As Ramdin notes of the new Sedition Ordinance, "in Port of Spain, Randolph Rust, the deputy mayor, condemned it, and in England the Labour Party Conference protested”. ${ }^{67}$

\section{Conclusion}

In 1982, C.L.R. James reflected that by the twentieth century,

the Caribbean people, on the whole, began to model what they need, particularly the working class, on the great discoveries and achievements of the working class abroad. What the Trinidad working class is demanding is not in its past history ... it has [been] ... afforded the great advantage in that the working class in Trinidad which wishes to transform itself is able to undertake what has taken the British, and others, two or three hundred years to learn. ${ }^{6}$

In 1919, we can clearly see this process beginning to develop - both in terms of the inspiration of the mass working class struggles in Britain and elsewhere but especially in the embryonic development of class unity between the East Indian agricultural labourers and the black oil workers and dockworkers - and this unity would deepen again during the mass strike of 1937. The militancy of a mass strike in a colonial dictatorship such as Trinidad,

\footnotetext{
63 Teelucksingh, Labour and the decolonisation struggle, 36-37.

64 Teelucksingh, Labour and the decolonisation struggle, 37; Singh, Race and Class Struggles, 32, 34.

${ }^{65}$ Singh, Race and Class Struggles, 33, 35-36.

${ }^{66}$ Campbell, “Carnival, Calypso and Class Struggle,” 20.

${ }^{67}$ Ramdin, From Chattel-slave to Wage-earner, 65; Samaroo, “The Trinidad Workingmen’s Association”, 216.

${ }^{68}$ C.L.R. James, “Introduction”, to Ron Ramdin, From Chattel-slave to Wage-earner: A History of Trade Unionism in Trinidad and Tobago, London, M. Brian \& O'Keeffe, 1982, 14.
} 
without such a well-established reformist Labour Party and trade union bureaucracy as in Britain, was arguably comparable to the mass strikes in Tsarist Russia.

An official report on the conduct of the police constabulary from September 1920 indeed noted that the "mutinous spirit" behind the dockworkers strike had begun with the Taranto revolt and "eventually reached the population of Trinidad generally". ${ }^{69}$ As Tony Martin judged, "the power of the people was such that with more sophisticated planning and a more self-conscious realization of their own strength they may have toppled British rule". ${ }^{70}$ It is certainly true that Trinidad in 1919 put the politics of Garveyism - as an expression of black nationalism at its most working class and radical - to the test, and found it wanting as a revolutionary ideology. Yet in a sense the other critical element missing was a strong clear sense in Trinidad that their movement had allies abroad, that there was a revolutionary movement taking place elsewhere, above all in imperial Britain, that might have stood with them in solidarity. Imagine if thanks to such a revolutionary movement Felix Hercules had been able to retain his internationalism while resident in imperial Britain, and so when addressing his audiences in Port of Spain in September 1919 been able to present another picture of British politics - one of mass strikes, solidarity and socialist agitation rather than just "the outrages seen in the race riots in London, Liverpool and Cardiff”? Imagine if Hercules had been able to bring with him greetings from socialist workers and messages of support from militant trade unionists in Britain...

As it was, the major international partner the TWA looked to in terms of the world working class movement was the British Labour Party, which was solidly committed to the maintenance of the British Empire, as its leadership had demonstrated during the First World War. Amid the Easter Rising in Ireland in 1916, the Labour Party leadership saw this as a treacherous stab in the back, and even the Independent Labour Party's Socialist Review argued that "we do not approve armed rebellion at all ... nor do we plead the rebels' cause ... nor do we complain against the Government for having opposed and suppressed armed rebellion by armed force". ${ }^{71}$ The main Labour paper, the Daily Herald accordingly only briefly reported "the official explanation" of the Trinidad revolt briefly in mid-December 1919 after it had come up in parliament. Its lack of interest and sympathy for what it called the "Negroes Revolt” might be detected from the racist ten-part children's cartoon poem by R. James Williams it had run from 24 November 1919 to 6 December 1919, "Nigger Brown in London Town”. ${ }^{72}$ The revolutionary Left in Britain in 1919 outside Labour was tiny and fragmented and would not come together to form the Communist Party of Great Britain (and

\footnotetext{
${ }^{69}$ Quoted in Elkins, “A Source of Black Nationalism in the Caribbean”, 103.

${ }^{70}$ Martin, “Revolutionary Upheaval in Trinidad”, 322.

${ }^{71}$ Socialist Review, Summer 1916, 205, quoted in Tony Cliff and Donny Gluckstein, The Labour Party: A Marxist History, London, Bookmarks, 1996, 87.

72 “Negroes Revolt - Trinidad Governor Besieged”, Daily Herald, 15 December 1919; “Trinidad Revolt - the official explanation”, Daily Herald, 16 December 1919. For the British parliamentary debate on the "Trinidad and Tobago disturbances” on 15 December 1919, see Hansard: https://hansard.parliament.uk/Commons/191912-15/debates/22d34579-fc51-4075-a467-b4874d69caeb/TrinidadAndTobago(Disturbances). The term "nigger brown" was a then popular name for a particular colour and this character was contrasted in the cartoon to "lily white” - another character - but this poem still represents an indefensible racist caricature.
} 
then slowly embrace a Leninist position on national liberation struggles) until 1920, after the revolt in Trinidad was over. ${ }^{73}$ Perhaps the clearest voice on the revolutionary left in Britain at the time challenging what Jonathan Hyslop has called the "white labourism" that beset and bedeviled the imperial British working-class came from the black Jamaican socialist poet and writer Claude McKay. On 31 January 1920, the Workers’ Dreadnought, edited by Sylvia Pankhurst, carried McKay’s article “Socialism and the Negro” on its front page, and McKay’s eloquent anti-imperialist argument repays quoting at length.

Some English Communists have remarked to me that they have no real sympathy for the Irish and Indian movement, because it is nationalistic. But today the British Empire is the greatest obstacle to International Socialism, and any of its subjugated parts succeeding in breaking away from it would be helping the cause of World Communism. In these pregnant times no people who are strong enough to throw off an imperial yoke will tamely submit to a system of local capitalism. The breaking up of the British Empire must either begin at home or abroad: the sooner the strong blow is struck the better it will be for all Communists. Hence the English revolutionary workers should not be unduly concerned over the manner in which the attack should begin. Unless, like some British intellectuals, they are enamoured of the idea of a Socialist (?) British Empire! ${ }^{74}$

\footnotetext{
${ }^{73}$ See the interesting exchange over colonialism at the Second Congress of the Communist International in 1920 between Lenin and Tom Quelch of the British Socialist Party. Ralph Fox, The Colonial Policy of British Imperialism, London, Martin Lawrence, 1933, 115-116.

${ }^{74}$ Claude McKay, “Socialism and the Negro”, Workers’ Dreadnought, 31 January 1920. See also Jonathan Hyslop, “The Imperial Working Class Makes Itself 'White’: White Labourism in Britain, Australia, and South Africa before the First World War,” Journal of Historical Sociology 12, no. 4 (1999): 398-421
} 


\section{Bibliography}

Bolland, O. Nigel. 1995. On the March: Labour Rebellions in the British Caribbean, 193439. Kingston: Ian Randle.

Campbell, Susan. 1988. Carnival, Calypso and Class Struggle in Nineteenth Century Trinidad. History Workshop Journal 26: 1-27.

Cliff, Tony and Gluckstein, Donny. 1996. The Labour Party: A Marxist History. London: Bookmarks.

Elkins, W.F. 1970. A Source of Black Nationalism in the Caribbean: The Revolt of the British West Indians Regiment at Taranto, Italy. Science and Society 34: 99-103.

Elkins, W.F. 1969. Black Power in the British West Indies: The Trinidad Longshoreman's Strike of 1919. Science and Society 33: 71-75.

Elkins, W.F. 1972. Hercules and the Society of Peoples of African Origin. Caribbean Studies 11, 4: 47-59.

Elkins, W.F. 1968. 'Unrest among the Negroes': A British document of 1919. Science and Society 32: 66-79.

Ewing, Adam. 2013. Caribbean labour politics in the age of Garvey, 1918-1938. Race \& Class 55, 1: 23-45.

Featherstone, David. 2018. Politicizing In/Security, Transnational Resistance, and the 1919 Riots in Cardiff and Liverpool. Small Axe 57: 56-67.

Fox, Ralph. 1933. The Colonial Policy of British Imperialism. London: Martin Lawrence.

Griffin, Paul. 2015. Labour struggles and the formation of demands: The spatial politics of Red Clydeside. Geoforum, 62: 121-130.

Hercules, F.E.M. 1918. The African and Nationalism. The African Telegraph, 1, 8: 84.

Hyslop, Jonathan. 1999. The Imperial Working Class Makes Itself 'White': White Labourism in Britain, Australia, and South Africa before the First World War. Journal of Historical Sociology 12, 4: 398-421

James, C.L.R. 1938. A History of Negro Revolt. London: FACT.

James, C.L.R. 1982. Introduction. In Ramdin, Ron, From Chattel-slave to Wage-earner: A History of Trade Unionism in Trinidad and Tobago. London: M. Brian \& O'Keeffe.

James, C.L.R. 2014. The Life of Captain Cipriani: An Account of British Government in the West Indies with the pamphlet The Case for West Indian Self-Government. Durham, NC: Duke University Press.

Jenkinson, Jacqueline. 2008. Black 1919: Riots, Racism and Resistance in Imperial Britain. Liverpool: Liverpool University Press.

Kiely, Ray. 1991. The Politics of Labour and Development in Trinidad and Tobago. PhD, University of Warwick. 
Martin, Tony. 1973. Revolutionary Upheaval in Trinidad, 1919: Views from British and American Sources. The Journal of Negro History, 58, 3: 313-326.

McKay, Claude. 1920. Socialism and the Negro. Workers’ Dreadnought, 31 January.

Ramdin, Ron. 1982. From Chattel-slave to Wage-earner: A History of Trade Unionism in Trinidad and Tobago. London: Martin Brian \& O'Keeffe.

Robinson, Cedric J. 1991. Black Marxism: The Making of the Black Radical Tradition. London: Zed.

Rosenberg, Chanie. 1987. 1919: Britain on the brink of revolution. London: Bookmarks.

Samaroo, Brinsley. 1972. The Trinidad Workingmen's Association and the Origins of Popular Protest in a Crown Colony. Social and Economic Studies 21, 2: 205-222.

Shawki, Ahmed. 2006. Black Liberation and Socialism. Chicago: Haymarket.

Singh, Kelvin. 1994. Race and Class Struggles in a Colonial State: Trinidad 1917-1945. Kingston: University of the West Indies Press.

Teelucksingh, Jerome. 2015. Labour and the decolonisation struggle in Trinidad and Tobago. Basingstoke: Palgrave Macmillan.

Virdee, Satnam. 2014. Racism, Class and the Racialised Outsider. Basingstoke, Palgrave Macmillan.

Worcester, Kent. 1996. C.L.R. James: A Political Biography. Albany: State University of New York Press. 